\title{
Molecular and morphological screening for net blotch resistance in some Egyptian barley cultivars
}

\author{
Ismael A. Khatab ${ }^{\mathbf{1}}$, Samah, A. Mariey ${ }^{\mathbf{2}}$ and Mona A. Farid ${ }^{\mathbf{1}}$ \\ 1. Department of Genetics, Faculty of Agriculture, Kafr El-sheikh University, 33516, Egypt \\ 2. Barley Research Department, Field Crops Research Institute, Agricultural Research Centre, Giza, Egypt
}

Corresponding author: ismael.khatab@yahoo.com

\begin{abstract}
Molecular and morphological screening analysis was evaluated to study the similarity levels and marker assisted selection associated with resistance to net blotch. Sequence-Related Amplified Polymorphism (SRAP) as a new marker was used on Egyptian barley for net blotch among 10 Egyptian barley cultivars. Five traits during two consecutive seasons and identify their reaction net blotch. The results exhibited a significant difference among studied cultivars for all traits. The highest mean values for all studied traits detected for, Giza 2000 and Giza 132 which they show resistance to net blotch. Molecular marker analysis using six selected primer combinations gave 56 total bands. Primer combination me5+em5 gave the highest polymorphism $(100 \%)$ and the highest polymorphic information content PIC was (0.96). However, primer combination me 5+em4 generated specific band associated to net blotch with size $\sim 1090 \mathrm{bp}$. The dendrogram clustered all studied cultivars into two main clusters each includes the most closed cultivars together according their reactions to net blotch. Results showed that the SRAP marker could be efficiently used to assess genetic variation among Egyptian barley and will be useful for barley germplasm management in terms of biodiversity protection and design of new crosses for disease resistance to net blotch breeding program.
\end{abstract}

Keywords: Hordeum vulgare, net blotch (Pyrenophora teres) Sequence-related amplified polymorphism (SRAP), UPGMA cluster analysis.

\section{Introduction}

Barley (Hordeum vulgare L.) is a cereal crop that is grown throughout the world and is ranked fifth in world crop production. Barley can be grown in many different climatic regions due to its adaptability to diverse conditions. These climatic conditions include variable growing seasons, temperatures, and precipitation rates (Pomeranz, 1987). Barley, like all crops, is attacked by many disease-causing organisms. Some cause only minor damage while others can completely destroy crops. One of the most devastating diseases is Net blotch, caused by the fungus Pyrenophora teres, is a common disease of barley; it is one of the most destructive foliar diseases of barley production in Egypt. Net blotch on barley can be controlled by the use of fungicides and/or resistant cultivars (Raman et al., 2003). Deployment of resistant cultivars is one of the most effective and economical means of controlling barley net blotch (Pyrenophora teres). Identification and incorporation of new and effective sources of resistance are crucial to the success of barley breeding programs. Thus molecular evaluation of barley germplasm is vital to enrich our knowledge on the abilities of existing germplasm and enabling us to predict hybrid vigor, choose parents used for crossing in crop development programs, and clone new natural plant resistance gene

Sequence related amplified polymorphism (SRAP) is a PCR based marker system as described by Li and Quiros (2001), is a simple, efficient marker system that can be adapted for a variety of purposes in different crops, reasonable throughput rate, discloses numerous co-dominant markers, targets open reading frames (ORFs), and allows easy isolation of bands for sequencing. SRAP markers are more reproducible, more stable, and less complex than RAPD and AFLPs. It could help to assess whether different management practices affect the genetic diversity of the individuals or populations. a few report on determining the genetic diversity and characterization of barley by SRAP as (Yang et al., 2008; 2010, Guo et al.,2012; Dizklrlcl et al 2012; Roberts and Wolfe 2014 ). SRAP was used to study leaf rust resistance in some Egyptian barley cultivars as reported for first time by (Mariey et al. 2015). Yet, there are no reports on determining the genetic diversity of Egyptian barley cultivars and or genotypes by SRAP markers for net blotch. Thus the objective of this present study is using the SRAP markers to investigate the genetic diversity of ten Egyptian barley cultivars for net blotch resistance in order to classify them on the molecular level and provide genetic information for the future breeding program.

\section{Materials and Methods}

\section{Plant Materials}

Ten barley cultivars (Hordeum vulgare L.) names and pedigree were used in this study as shown in Table 1. Barley cultivars were grown in the experimental research farm of EL- Nubaria Station during two growing seasons 2015/2016 and 2016/2017 to evaluated yield and its components traits and their reaction to net blotch. The experiments during the two seasons were growing using randomized complete block design with three replications. Plot size (experimental unit) was $1.8 \mathrm{~m}^{2}$ (6 rows $\mathrm{x} 0.2 \mathrm{~m} \mathrm{x}$ 
$1.5 \mathrm{~m})$. Five studied traits were recorded in this study; plant height $(\mathrm{cm})$, number of spikes $\mathrm{m}^{-2}$, number of grains spike ${ }^{-1}$, grain yield $\mathrm{t} \mathrm{fed}^{-1}$ and the net blotch reaction.

Table 1. Name, row type and pedigree of 10 barley cultivars used

\begin{tabular}{|c|c|c|c|c|}
\hline No. & Name & Row & ype & Pedigree \\
\hline 1 & Giza 123 & covered & 6 row & Giza 117/FAO 86 \\
\hline 2 & Giza 129 & naked & 6 row & Deir Alla 106/Cel//As46/Aths*2" \\
\hline 3 & Giza 130 & naked & 6 row & Comp.cross"229//Bco.Mr./DZ02391/3/Deir Alla 106 \\
\hline 4 & Giza 131 & naked & 6 row & $\begin{array}{l}\text { CM67B/CENTENO//CAMB/3/ROW906.73/4/GLORIABAR/ COME- } \\
\text { B/5/FALCON BAR/6/LINO }\end{array}$ \\
\hline 5 & Giza 132 & covered & 6 row & Rihane-05//AS 46/Aths*2Athe/ Lignee 686 \\
\hline 6 & Giza 133 & covered & 6 row & ICB91-0343-0AP-0AP-0AP-281AP-0AP \\
\hline 7 & Giza 134 & covered & 6 row & ICB91-0343-0AP-0AP-0AP-289AP-0AP \\
\hline 6 & Giza 135 & naked & 6 row & ZARZA/BERMEJO/4/DS4931//GLORIABAR/COPAL/3/SEN/5/AYAROS \\
\hline 9 & Giza 136 & naked & 6 row & $\begin{array}{l}\text { PLAISANT/7/CLN-B/LIGEE640/3/S.P-B//GLORIAAR/ COME } \\
\text { B/5/FALCONBAR/6/LINOCLN-B/A/S.P-/LIGNEE640/3/S.P- } \\
\text { B//GLORIA-BAR/COME B/5/FALCONBAR/6/LINO }\end{array}$ \\
\hline 10 & Giza 2000 & covered & 6 row & Giza117/Bahteem52// Giza118/ FAO86 / 3/Baladi16/ Gem \\
\hline
\end{tabular}

\section{Molecular Analysis}

\section{SRAP-PCR Amplification}

Genomic DNA was isolated from ten barley cultivars fresh leaves using CTAB method according to Doyle and Doyle (1990), using six SRAP primer combinations, their names and sequences were shown in (Table 2). PCR cycling was carried out as the following program; initial denaturation at $94{ }^{\circ} \mathrm{C}$ for $4 \mathrm{~min}$, followed by five cycles comprising for 1 -min denaturation at $94{ }^{\circ} \mathrm{C}, 1$-min annealing at $35{ }^{\circ} \mathrm{C}$, and $30 \mathrm{~s}$ of elongation at $72^{\circ} \mathrm{C}$. In the following 30 cycles, denaturation at $94{ }^{\circ} \mathrm{C}$ for $1 \mathrm{~min}$, annealing at $50{ }^{\circ} \mathrm{C}$ for $1 \mathrm{~min}$, and elongation at $72{ }^{\circ} \mathrm{C}$ for $30 \mathrm{~s}$ were carried out, ending with an elongation step for $10 \mathrm{~min}$ at $72{ }^{\circ} \mathrm{C}$. The amplified products were stored at $4{ }^{\circ} \mathrm{C}$. The PCR products were separated by electrophoresis using $1.8 \%$ agarose gel in $1 \mathrm{x}$ TAE buffer against 100 bp DNA Ladder as a size marker. Bands were detected with ethidium bromide staining and visualized under UV light, then photographed on Gel Documentation

Data Analysis

Morphological traits analysis,

Data collected from field experimental were statistically analyzed as a randomized complete block design (RCBD) using analysis of variance (ANOVA) for each season and over all the two seasons as a combined analysis, all data collected were subjected to statistical analysis of variance (Steel et al. 1997). Principal component and cluster analysis were analysis using a computer software program Minitab v.12. Cultivars were clustered using un-weighted pair group method using arithmetic average as outlined by Kovach (1995).

\section{SRAP markers data analysis:}

The amplified bands from SRAP were scored as a binary data under the heading of total storable fragments which determined for each cultivar. The data were used to estimate the genetic similarity on the basis of number of shared amplification products (Nei and $\mathrm{Li}, 1979$ ). Polymorphism information content (PIC) values were done to distinguish between cultivars for each primer according (Anderson et al. 1993). Cluster analysis was performed to produce a denderogram using unweighted pair-group method with arithmetical average (UPGMA) based on JukesCantor coefficient using PAST program adapted by Hammer et al. (2001).

Table 2. SRAP Primers combinations name and sequences

\begin{tabular}{lll}
\hline Name & \multicolumn{1}{c}{ Forward primer sequences } & \multicolumn{1}{c}{ Reverse primer sequences } \\
\hline me1+em2 & TGAGTCCAAACCGGATA & GACTGCGTACGAATTTGC \\
\hline me1+em3 & TGAGTCCAAACCGGATA & GACTGCGTACGAATTGAC \\
\hline me2+em1 & TGAGTCCAAACCGGAGC & GACTGCGTACGAATTAAT \\
\hline me2+em2 & TGAGTCCAAACCGGAGC & GACTGCGTACGAATTTGC \\
\hline me5+em4 & TGAGTCCAAACCGGAGC & GACTGCGTACGAATTGAC \\
\hline me5+em5 & GAGTCCAAACCGGAAG & GACTGCGTACGAATTAAT \\
\hline
\end{tabular}

\section{Results and discussion}

\section{Morphological traits analysis}

Phenotypic diversity of barley for their reaction to net blotch was assessed using both quantitative and qualitative traits are shown in Table 3. Results exhibited significant differences among the cultivars for all studied traits. The results clearly indicated that the ten used cultivars differed significantly in plant height; Giza 133 was the tallest in each individual 
season and overall the two seasons recording 106.7, 110 and $108.3 \mathrm{~cm}$, respectively. The significant differences in plant height among barley cultivars might be attributed to the differences in their genetically structure. These results are in agreement with those of El-Hindi et al. (1998), Assad et al. (1998) and Afiah and Moselhy (2001). Concerning number of spikes $\mathrm{m}^{-2}$, the means of the cultivars given in Table 3 show that the cultivar Giza 123 gave the highest number of spikes $\mathrm{m}^{-2}$ in the first season, second season and across their combined with values of $\left(514.7,501.3\right.$ and 508.0 spikes $\mathrm{m}^{-2}$ ) respectively. Data of number of grains spike ${ }^{-1}$ revealed that Giza 136 produced the highest no. of grains spike ${ }^{-1}$ in each individual season and inclusive the two seasons recording 64.5, 65.5 and 65.0 grains spike $^{-1}$, respectively. These results were in agreement with those obtained by Hradecka (1994), and Afifi (1999).
Regarding grain yield, significant differences among barley genotypes were detected in and over the two seasons, data indicated that the Egyptian barley cultivar, Giza 135 gave the maximum values in first season with was $\left(3.7 \mathrm{t} \mathrm{fed}^{-1}\right)$ and in second season Giza 134 gave the maximum value was $\left(4.2 \mathrm{t} \mathrm{fed}^{-1}\right)$ as well as over the two seasons both Giza129 had the maximum value was $3.5 \mathrm{t} \mathrm{fed}^{-1}$. These results were in agreement with those of Noaman et al. (1997), Afiah and Moselhey (2001), and Assad et al. (1998). High significant for all traits recorded and over the two seasons were significant, also the interaction between cultivars and the seasons were also high significant for all traits. Such results indicated that the tested cultivars varied from each other and ranked differently from season to other. These findings are in harmony with reports of Jackson et al. (1994), Dwyer et al. (2001)

Table 3. Means square of plant height and no. spikes $\mathrm{m}^{-2}$, no. grains spike ${ }^{-1}$, grain yield and net blotch reaction of ten Egyptian barley cultivars grown under el- nobria station during two growing seasons 2015/2016 and 2016/2017

\begin{tabular}{|c|c|c|c|c|c|c|c|c|c|c|c|c|c|c|c|}
\hline \multirow{2}{*}{ cultivars } & \multicolumn{3}{|c|}{ plant height $(\mathrm{cm})$} & \multicolumn{3}{|c|}{ number spikes $\mathrm{m}^{-2}$} & \multicolumn{3}{|c|}{ Number grain spike ${ }^{-1}$} & \multicolumn{3}{|c|}{ grain yield $\mathrm{t} \mathrm{fed}^{-1}$} & \multicolumn{3}{|c|}{ net blotch reaction } \\
\hline & Ses1 & Ses2 & Com. & Ses1 & Ses2 & Com. & Ses 1 & Ses2 & Com. & Ses 1 & Ses2 & Com. & Ses 1 & Ses2 & Com. \\
\hline Giza123 & 91.7 & 93.3 & 92.5 & 514.7 & 501.3 & 508.0 & 60.8 & 62.2 & 61.5 & 2.3 & 4.0 & 3.2 & 4.8 & 4.3 & 4.6 \\
\hline Giza2000 & 95.0 & 104.3 & 99.7 & 440.0 & 461.3 & 450.7 & 56.8 & 64.2 & 60.5 & 3.3 & 3.5 & 3.4 & 3.2 & 3.0 & 3.1 \\
\hline Giza132 & 88.3 & 90.5 & 105.8 & 369.3 & 440.0 & 404.7 & 61.8 & 63.2 & 62.5 & 3.3 & 3.4 & 3.4 & 3.0 & 3.2 & 3.1 \\
\hline Giza133 & 106.7 & 110.0 & 108.3 & 444.0 & 457.3 & 450.7 & 60.8 & 61.8 & 61.3 & 1.4 & 2.1 & 1.8 & 4.8 & 5.8 & 5.05 \\
\hline Giza134 & 105.0 & 108.3 & 106.7 & 465.3 & 461.3 & 513.3 & 62.5 & 64.5 & 63.5 & 3.2 & 4.2 & 3.7 & 4.2 & 4.4 & 4.3 \\
\hline Giza135 & 95.0 & 103.0 & 99.0 & 490.7 & 500.0 & 505.3 & 60.5 & 64.5 & 62.5 & 3.7 & 3.4 & 3.5 & 5.8 & 5.5 & 5.7 \\
\hline Giza136 & 90.0 & 120.0 & 105.0 & 498.7 & 449.3 & 474.0 & 64.5 & 65.5 & 65.0 & 3.2 & 3.5 & 3.3 & 8.0 & 7.6 & 7.8 \\
\hline Giza129 & 98.3 & 96.7 & 97.5 & 400.0 & 534.7 & 467.3 & 60.5 & 63.5 & 62.0 & 3.3 & 3.8 & 3.5 & 7.5 & 7.5 & 7.5 \\
\hline Giza130 & 103.3 & 105.0 & 114.2 & 490.7 & 504.0 & 497.3 & 62.2 & 62.8 & 62.5 & 3.4 & 3.1 & 3.3 & 5.0 & 5.3 & 5.2 \\
\hline Giza131 & 95.0 & 76.7 & 85.8 & 348.0 & 397.3 & 372.7 & 61.8 & 61.5 & 61.7 & 2.9 & 2.9 & 2.9 & 4.0 & 4.2 & 4.10 \\
\hline average & 96.8 & 106.1 & 101.5 & 446.1 & 482.7 & 464.4 & 61.2 & 63.4 & 62.3 & 3.0 & 3.4 & 3.2 & 5.0 & 5.1 & 5.0 \\
\hline LSD 0.5 & 3.7 & 9.8 & 0.97 & 1.44 & 1.4 & 0.97 & 3.9 & 0.48 & 2.7 & 3.01 & 2.7 & 1.36 & 1.44 & 9.6 & 0.98 \\
\hline CV\% & 3.9 & 1.1 & 2.1 & 10.3 & 10.4 & 10.6 & 5.8 & 5.8 & 6.7 & 15.9 & 14.3 & 14.9 & 1.53 & 1.09 & 5.10 \\
\hline F Test & $* *$ & $* *$ & $* *$ & $* *$ & $* *$ & $* *$ & $* *$ & $* *$ & $* *$ & $* *$ & $* *$ & $* *$ & $* *$ & $* *$ & $* *$ \\
\hline $\mathrm{C} \times \mathrm{S}$ & $* *$ & $* *$ & NS & $* *$ & $* *$ & NS & $* *$ & $* *$ & $* *$ & $* *$ & $* *$ & $* *$ & $* *$ & $* *$ & $* *$ \\
\hline
\end{tabular}

\section{Inoculation and net blotch disease reaction on barley cultivars}

Disease assessment was done on a scale of 0-9 severity scale with 0 representing no infection and 9 when all barley leaves dry due to infection by the fungus (Couture, 1980; Xue et al., 1994). During the assessment seedling response data was scored at 21 days while adult plant response data was scored at 63 days and 91 days. After assessment, the barley cultivars were grouped as follows: $0-3=$ Resistant, 4 $5=$ moderately resistant, 6-7 = moderately susceptible, $8-9=$ Susceptible. According this scale from our data in Table 4 we found that the highest values in first and second seasons were recorded for Giza 136 with (8.0 and 7.5) and Giza 129 with (7.5 and 7.5) respectively, which it could be consider as a s susceptible cultivars. On the other hand, Giza 132 and Giza 2000 had the lowest values in both two seasons so we considerate it as resistance cultivars and other cultivars ranged between moderately resistant and moderately susceptible. These results are in good harmony with report published by Khatab et al., (2013).

The different response of barley cultivars to disease confirms that they were genetically controlled by several resistance genes (Owino et al., 2014). Maximum spore production has been reported to occur at $25^{\circ} \mathrm{C}$ and at a high relative humidity (Kosiada, 2008). High temperatures coupled with higher relative humidity at El-Nobaria station may have preferential spore production and multiple infections of genotypes, these conditions may have contributed to the observed significant variations in disease response in the two seasons. Higher amounts of rainfall observed in both 
seasons at early growth stages may caused a rise in moisture levels in the host plants thus causing increased infection by the pathogens (Agrios, 2005 and EL-Banna et al. 2011). The difference in severity levels in different sites may also have been influenced by the presence of different pathogen isolates in the sites (Were and Ochuodho, 2012). A significant interaction between genotype and environment has also been showed to affect the level of disease epidemics in different (Cherif et al., 2010).

\section{Cluster analysis based on morphological and net blotch reaction}

Results of cluster analysis are displayed in Table 4 and graphically illustrated in dendrogram Fig. 1.Results of cluster analysis indicated the similarity levels between all the cultivars according their morphological study and their reaction to net blotch , was done by parallel matrix based on Euclidean distance measurement and non-weighted paired group method using mathematics average (UPGMA). Results of cluster analysis indicated that all cultivars were classified into four groups: (R) group include the resistance cultivars (Giza 2000 and Giza 132), group (S) include the susceptible cultivars together (Giza 129 and Giza 136), (MR) group include the moderate resistance cultivars (Giza 133, Giza 130 and Giza 135) and MS group moderate susceptible cultivars include (Giza 123, Giza 134 and Giza 131). The highest similarity level in Table 4, was recorded between two cultivars Giza 133 and Giza 130 equaled $97.26 \%$ similarity, while the lowest similarity levels was obtained between Giza 123 and Giza 136 was 30.34\% similarity. It is notable that cluster analysis measured a valuable tool for dividing number of cultivars in groups including similarity and dissimilarity cultivars which would help the breeder to design an effective breeding program.

Table 4. Cluster analysis to classify ten barley cultivars based on agro-morphological traits and the net blotch reaction

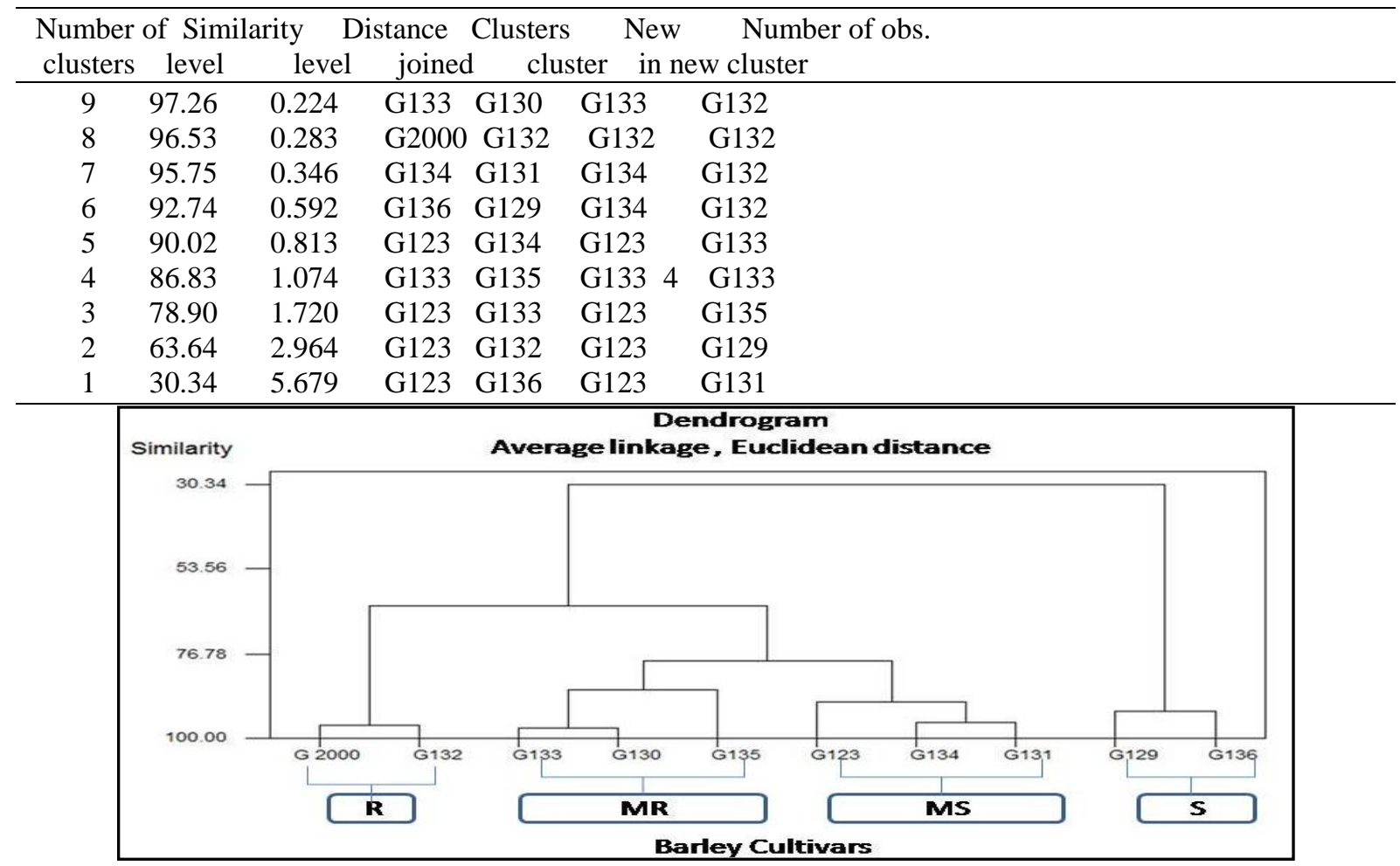

Fig 1 Dendrogram based on UPGMA cluster analysis showing the genetic similarity percentage between the ten studied barley genotypes based on morphological traits and net blotch reaction

\section{Molecular marker analysis}

Evaluation of genetic diversity and relationships among different cultivars is vital importance for plant breeding programs. Molecular markers have been shown to be a very powerful tool for genotype characterization and evaluation the genetic diversity. In the present study, SRAP marker systems was first time applied to assess the level of genetic diversity of ten Egyptian barley cultivars for their response to net blotch. total of 56 fragments were amplified with 6 primer combinations, Results in Table 4 showed the average percentage of polymorphic loci for all primer combinations was $77.67 \%$ and the average band number amplified from each pair of primers was 9.33\% bands, of which included $7.5 \%$ polymorphic bands, which the maximum band number among the six primers combinations was 14 obtained by primer combination me5+em5 which gave the highest polymorphism (100\%) Fig (2), and primer me5+em4 gave $(88.89 \%)$ and generated specific band associated 
to net blotch with size $\sim 1090 \mathrm{bp}$. However, primer me1+em2 had the lowest polymorphism $(57.4 .0 \%)$. Polymorphic information content (PIC) values which were used to measure the genetic diversity were varied from 0.58 to 0.96 , the highest (PIC), was related to primer combination me5+em5 was (0.96) indicating that this primer combination is highly informative and might be useful tool to determine the genetic differences among barley cultivars .

Table 4. Polymorphism number and rate for six SRAP primer pairs used to amplify genomic DNA templates from ten Egyptian barley cultivars

\begin{tabular}{ccccc}
\hline $\begin{array}{c}\text { Primer } \\
\text { combination }\end{array}$ & $\begin{array}{c}\text { Number of } \\
\text { Total fragments }\end{array}$ & $\begin{array}{c}\text { Number of } \\
\text { polymorphic } \\
\text { fragments }\end{array}$ & $\begin{array}{c}\text { Percentage of } \\
\text { polymorphic } \\
\text { fragments }\end{array}$ & polymorphic information content (PIC) \\
\hline me1+em2 & 7 & 4 & 57.14 & 0.58 \\
\hline me1+em3 & 8 & 6 & 75.00 & 0.76 \\
\hline me2+em1 & 10 & 7 & 70.00 & 0.71 \\
\hline me2+em3 & 8 & 6 & 75.00 & 0.83 \\
\hline me5+em4 & 9 & 8 & 88.89 & 0.96 \\
\hline me5+em5 & 14 & 14 & 100.00 & \\
\hline Average & 9.33 & 7.5 & 77.67 & \\
\hline total & 56 & 45 & & \\
\hline
\end{tabular}

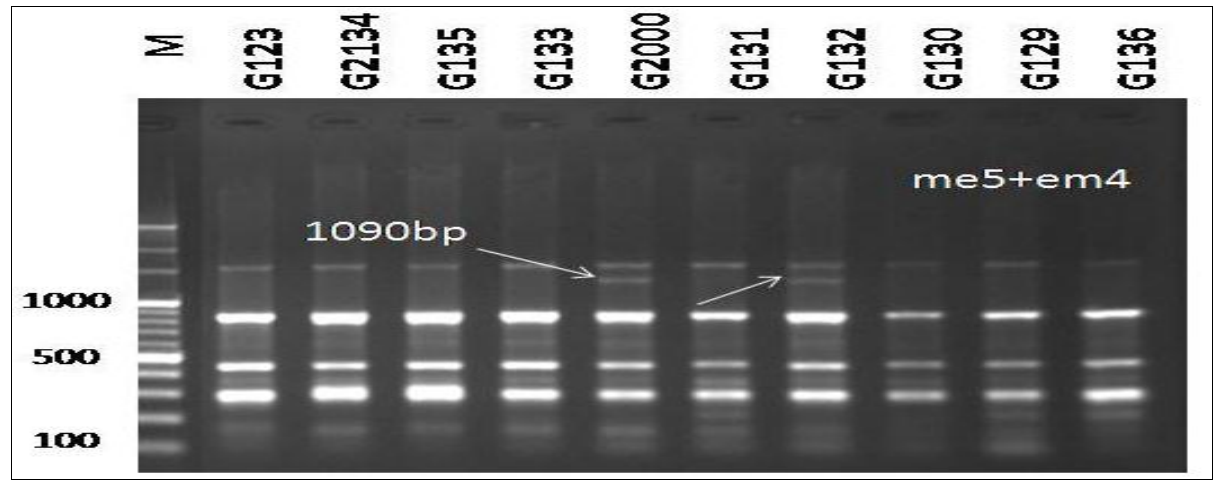

Fig 2. Agarose gel electrophoresis of SRAP amplification products of different ten barley.

Arrows point to the polymorphic bands of interest.

The dendrogam was constructed by the Unweighted Pair-Group Method (UPGMA) based on Jaccard's genetic similarity coefficient of the ten barley cultivars (Fig. 3). were classified into two major clusters, first cluster include resistance cultivar (R) Giza 2000 and Giza 132 and MR (Giza 135, Giza
123, Giza 130 and Giza 131), while the second cluster include the suspitale S cultivars such as Giza 136 and Giza 129 and MS cultivars such as Giza134 and Giza 133), the genetic similarity coefficient among barley cultivars ranged from $95 \%$ to $66 \%$ as shown in Table 5 .

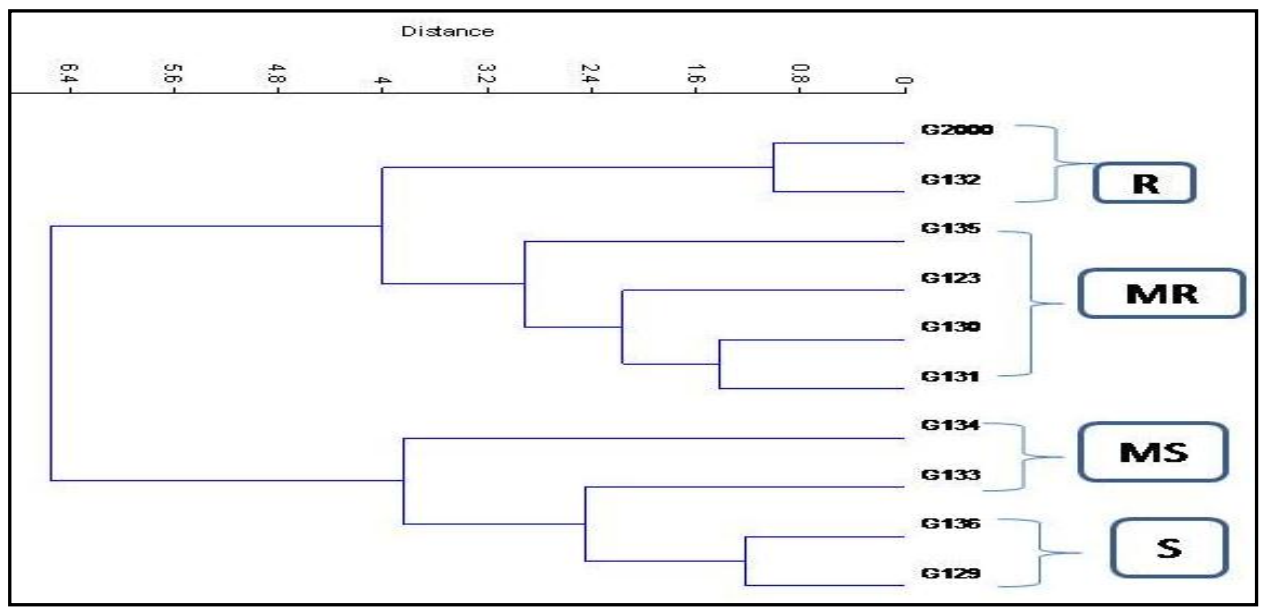

Fig 3. Dendrogram based on UPGMA cluster analysis showing the genetic similarity percentage between the ten studied barley genotypes based on SRAP marker 
Table 5. Genetic similarity (GS) matrix for ten barley cultivars based on SRAP marker

\begin{tabular}{|c|c|c|c|c|c|c|c|c|c|c|}
\hline & G123 & G2000 & G132 & G133 & G134 & G135 & G136 & G129 & G130 & G131 \\
\hline G2000 & 0.86 & 1.00 & & & & & & & & \\
\hline G132 & 0.82 & 0.95 & 1.00 & & & & & & & \\
\hline G133 & 0.83 & 0.78 & 0.74 & 1.00 & & & & & & \\
\hline G134 & 0.74 & 0.70 & 0.66 & 0.74 & 1.00 & & & & & \\
\hline G135 & 0.83 & 0.83 & 0.78 & 0.79 & 0.74 & 1.00 & & & & \\
\hline G136 & 0.78 & 0.74 & 0.70 & 0.82 & 0.73 & 0.75 & 1.00 & & & \\
\hline G129 & 0.80 & 0.76 & 0.72 & 0.84 & 0.75 & 0.77 & 0.93 & 1.00 & & \\
\hline G130 & 0.89 & 0.84 & 0.80 & 0.84 & 0.72 & 0.85 & 0.84 & 0.86 & & \\
\hline G131 & 0.89 & 0.89 & 0.84 & 0.81 & 0.75 & 0.89 & 0.77 & 0.79 & 0.91 & 1.00 \\
\hline
\end{tabular}

In present study, genetic diversity level of Egyptian barley cultivars for net blotch is higher than other genetic diversity studies using different marker systems with barley for net blotch such as RAPD and ISSR (Khatab et al., 2013), SSR (Saker 2005) QTL ( Adowy et al 2013). SRAP markers mainly targets exons which are expected to be evenly distributed along all chromosomes with GC-rich regions and introns with AT-rich regions (Li and Quiros, 2001). Small and simple barley genome taken into consideration, many intron and exon regions may have influenced the number of excess polymorphic bands. These results were in a good harmony with (Saker 2005, Khatab et al. 2013)

\section{References}

Adawy, S. S., A. A. Diab, A. I. Sayed, S. D. Ibrahim, S. I. El-Morsy and M. M. Saker (2013). Construction of genetic linkage map and QTL analysis of net blotch resistance in barley. IJABR, 4: 348-363.

Afiah, S.A.N., and Moselhy, N.M.M. (2001). Evaluation of selected barley genotypes under rainfed conditions of , North Western Coast, Egypt. Annals of Agricultural Science, Cairo. (2001). 46(2):619-629.

Agrios, G. N. (2005). Plant pathology. $5^{\text {th }}$ Edition. Elsevier Academic Press, UK.

Anderson, J. A., Churchill ,G. A., Autrique, Tanksley J. E., S. D and ,M. E,. (1993) Optimizing parental selection for genetic linkage maps. Genome. 36, 181-186

Assad, F.A., Noaman, M.M. Elsayed A.A. and Elbawab, A.O. (1998). Developing high-yielding barley cultivars under different stress conditions in Egypt. Egyptian Journal of Agricultural Research, 76(3):1037-1061.

Cherif M., Rezgui S., Devaux P., Harrabi M. (2010) Genotype $\mathrm{X}$ enviroment interactions and heritability of quantitative resistance to net blotch in Tunisian barley. Plant breeding and crop science 2: 110-116.

Couture L. (1980) Assesment of severity of foliage diseases in cooperative evaluation tests. Plant Disease Survay. 60:8-10.
Dizklrlcl, A., Kaya, Z., Guren,H and Budak (2010). Barley germplasms developed for scald disease resistance exhibited a high level of genetic diversity based on SRAP markers. Turk J Biol 34 :271-279.

Doyle, J.J. and Doyle, J.L. (1990).A rapid DNA isolation procedure for small quantities of fresh leaf tissue .Focus, 12,13-15.

Dwyer, L.M., Ma, L.B., Choo, T.M., Ho, K.M., Martin R.A. and Fregeau, J. (2001). Utilization of physiological traits for selection of high-yielding double haploid barley. Canadian Journal of Plant Science, 81(4):587-594.

El-Banna M., Nassar M., Noaman M.and Boseely M. (2011) Evaluation of 16 Barley Genotypes under Calcareous Soil Conditions in Egypt. Journal of Agricultural Science. 3, 1: 105-121

El-Hindi, M.H, El-Kassabey, A.T., Sharief, A.E. and Amer, K.A. (1998). Yield of barley as affected by different sources and levels of nitrogen fertilization under the environmental conditions of newly reclaimed soils a northern delta of Egypt .Proc.8th winter barley in rainfed conditions of the Central Anatolian Region. Journal of Crop Research/Bitkisel Arastirma Dergisi, 1(1):11-16.

Guo, L., Liu, X., Liu, X., Yang, Z., Kong, D ., He, Y and Feng, $Z$ (2012). Construction of genetic map in barley using sequence-related amplified polymorphism markers, a new molecular marker technique. African Journal of Biotechnology Vol. 11(74), pp. 13858-13862.

Hammer $\varnothing$.; D.A.T. Harper; P.D. Ryan and PAST (2001) Paleontological statistics software package for education and data analysis, Palaeontologia Electronica, 4, 1-9.

Hradecka, D. (1994). Influence of alginate application on growth and yield formation of malting spring barley.

Jackson, P.A., Byth, D.E. Fischer, K.S. and Johnston, R.P. (1994). Genotype x environment interaction in progeny from barley cross variation in grain Yield, Yield components and dry matter Production among lines with similar times to anthesis. Field Crops Res. (37), Issue 1, April 1994:11-23.

Khatab,A. Ismael, Mareiy, A. Samah, Eid ,A..A. and Noman, M. M. (2013) Efficiency of RAPD and 
ISSR markers in assessing barley genotypes resistance to net blotch. World Research Journal of Agricultural Biotechnology. Vol. 2, Issue 1, 2124

Kosiada, T. (2008). Influence of temperature temperature and daylight length on barley infection by Pyrenophora teres. Plant Protection Res., 48: 9-15.

Kovach, W. I. 1995 A multivariate statistics package for IBM P and compatibles, Kovach Computing Service, 85 Nant-Y- Felin, Pentreaeth, Anglesely LL 758 UY Wales, U.K.

Li, G. and Quiros, C.F (2001) Sequence-related amplified polymorphism (SRAP) a new marker system based on a simple PCR reaction, its application to mapping and gene tagging in Brassica. Theor. Appl. Genet. 103, 455-461.

Mariey, A. Samah (2018) Genetic Diversity Study of Egyptian Barley Cultivars using SequenceRelated Amplified Polymorphism (SRAP) Analysis for Water Stress Tolerance .J. Sus. Agric. Sci. in press.

Mariey, A. Samah, Khatab I.A. and Kumamaru, T. (2015) Molecular markers associated with resistance to leaf rust among some barley genotypes. Egypt. J. Agric . Res. 93,413-421

Minitab, (1996) Minitab for widows release 11.12.Cited http://www.cit.cornell.edu/sitelicenses/minitab.html.

Nei, M. and Li, W.H. (1979) Mathematical model for studying genetic variation in terms of restriction endonucleases. Proc. Natl. Acad. Sci., 76,52695273

Owino, A. A., J. O. Ochuodho, J. O. Were and N. Rop (2014). Response of spring and winter barley to Pyrenophora teres under high and medium altitude zones of Kenya. Int. J. of Res. in Agri. and Food Sci., 2: 2311-2476.

Pomeranz, Y. (1987). Modern Cereal Science and Technology. VCH Publishers, Inc

Robarts, D.W.H. and Wolfe, A.D (2014). Sequencerelated amplified polymorphism (SRAP) markers: A Potential resource for studies in plant. Applications in Plant Sciences 2 ( 7 ): 1400017.

Sakar, M. M. (2005). Mapping RAPD and SSR markers linked to net blotch resistance gene in barley Arab J. Biotech., Vol. 8, No. (2): 369-378.

Steel, R.G.D., Torrie, J.H. and Deekey, D.T. (1997) Principles and procedures of statistics: "A Biometrical Approach" 3rd ed., McGraw Hill Book Co., Inc. New York

Were J.O., Ochuodho J.O. (2012) Effects of Sorghum bicolor traits on resistance to foliar anthracnose (Colletotrichum sublineolum) in the lake basin regions of Kenya. International Journal of Current Research 4(12): 537-542

Xue G., Burnett P.A., Helm J. (1994) Severity of, and resistance of barley varieties to scald and net blotch in Central Alberta. Plant Disease Survey 74:13-17.

Yang P, Liu, X.J., Liu, X.C., Li J., Wang, X.W., He, S.P., Li, G., Yang, W.Y. and Feng, Z.Y. (2008) Genetic diversity analysis of the developed qingke (hulless barley) varieties from the plateau regions of Sichuan province in China revealed by SRAP markers. Hereditas (Beijing), 30, 115-122

Yang, P., Liu, X., Liu, X., Yang, W and Feng, Z (2010). Diversity analysis of the developed qingke (hulless barley) cultivars representing different growing regions of the Qinghai-Tibet Plateau in China using sequencerelated amplified polymorphism (SRAP) markers. African Journal of Biotechnology Vol. 9(50), pp. 8530-8538. 
